\title{
PENENTUAN KADAR TIMBAL DALAM DARAH OPERATOR SPBU DI KOTA KARANGANYAR BERDASARKAN KEBIASAAN MEROKOK
}

\author{
Determination Of Lead Levels In Blood Operator SPBU In The City Of Karanganyar \\ Based On Smoking Habit
}

\author{
Tri Harningsih ${ }^{\text {* }}$ \\ Wimpy ${ }^{2}$ \\ *ISekolah Tinggi Ilmu Kesehatan \\ Nasional,Surakarta,Jawa \\ Tengah, Indonesia \\ 2Sekolah Tinggi Ilmu Kesehatan \\ Nasional,Surakarta,Jawa \\ Tengah, Indonesia \\ *email: \\ tri.harningsih@gmail.com
}

\section{Kata Kunci:}

cross sectional, merokok,operator, pengambilan sampel purposive, pompa bensin, timah

\section{Keywords:}

cross sectional, smoking operators lead purposive sampling, gas station

\begin{abstract}
Abstrak
Timbal adalah campuran bahan pembuatan bensin yang memiliki fungsi anti-ketukan pada mesin kendaraan. Asap gas buang kendaraan karena proses pembakaran yang sempurna dibuang ke udara. Operator pompa bensin adalah pekerja yang berisiko tinggi terkena timbal. Penelitian ini dilakukan untuk menggambarkan kadar timbal dalam darah operator SPBU berdasarkan kebiasaan merokok. Jenis penelitian ini adalah deskriptif dengan menggunakan pendekatan cross sectional. Penelitian dilakukan pada bulan Mei-Agustus 2019. Sampel diambil dengan teknik purposive sampling dan diperoleh sampel dari 5 operator pompa bensin di wilayah Karanganyar. Pemeriksaan kadar timbal dalam darah menggunakan Spektrofotometer Serapan Atom AA 7000. Hasil penelitian ini adalah untuk mendapatkan kadar timbal darah di semua operator diperiksa dengan kode AI, A2, A3, A4, A5 yang masing-masing adalah I,7854 $\mathrm{g} / \mathrm{dl} ;$ I,2049 $\mu \mathrm{g} / \mathrm{dl}$; I,6656 ug /dl; I,2825 ug /dl; I,4950 ug /dl. Responden dengan kebiasaan merokok 20 batang/hari memiliki kadar timah hitam tertinggi di antara semua responden. Semua operator pompa bensin dengan kebiasaan merokok setiap hari memiliki kadar timah hitam pada ambang normal yang ditetapkan oleh CDC (Pusat Pengendalian dan Pencegahan Penyakit), yaitu $<10 \mu \mathrm{g} /$ dl.
\end{abstract}

\section{PENDAHULUAN}

Pencemaran udara adalah adanya zat, energi, dan/atau komponen lain pada udara oleh kegiatan manusia, sehingga mutu udara turun dan menyebabkan udara tidak dapat memenuhi fungsinya (Hasbiah, dkk, 2016). Pencemaran udara dapat berasal dari asap cerobong industri, gas buang kendaraan bermotor. Permasalahan lingkungan merupakan hal yang sangat penting untuk segera diselesaikan karena menyangkut kesehatan, kehidupan manusia. Perkembangan di dunia otomotif sebagai alat transportasi akan memudahkan manusia dalam melakukan pekerjaan, disisi lain penggunaan kendaraan bermotor akan menimbulkan dampak negatif bagi lingkungan terutama gas buang dari pembakaran bahan bakar yang tidak terbakar atau terurai sempurna 
(Gusnita, 20I2). Sebagai negara berkembang Indonesia masih mengalami permasalahan polusi udara yang sudah sangat perlu diperhatikan dimana kondisi yang cukup memprihatinkan akibat dari gas buang kendaraan bermotor terutama di kota-kota besar. Peningkatan jumlah kendaraan bermotor akan meningkatkan konsumsi bahan bakar minyak serta memberikan kontribusi pencemaran udara di Indonesia.

Transportasi di kota kota besar merupakan pencemaran udara terbesar dan sekitar $70 \%$ disebabkan oleh aktivitas dari kendaraan bermotor. Sejalan dengan meningkatnya jumlah kendaraan bermotor maka akan meningkatkan pembakaran bahan bakar berminyak (BBM), dan akan diperparah dengan kemacetan lalu lintas yang menyebabkan polusi terjadi dimana-mana (Suhardjo, 2007). Partikel yang banyak terdapat di lingkungan di antaranya adalah debu, dan timbal (Naria, 2005).

Penelitian yang dilakukan oleh Ayu et al., (2016) mengenai "Hubungan Karakteristik pekerjaan dengan kadar timbal dalam darah pada operator SPBU di kecamatan Tamalanrea kota Makassar" menunjukkan hasil dari $5 \mathrm{I}$ responden yang diperiksa, sebanyak 24 orang responden memiliki kadar timbal dalam darah sebesar $>25 \mu \mathrm{g} / \mathrm{dl}, 19$ orang memiliki kadar timbal 10 $25 \mu \mathrm{g} / \mathrm{dl}$, dan sisanya memiliki kadar timbal <10 $\mu \mathrm{g} / \mathrm{dl}$. Kadar timbal yang melebihi batas normal dapat memberikan dampak terhadap kesehatan pekerja. Penelitian Laila dan Shofwati (2013) “Kadar Timbal Darah dan Keluhan Kesehatan Pada Operator Wanita SPBU" terdapat 10 responden dengan kadar timbal > 10 $\mu \mathrm{g} / \mathrm{dl}$ dari 34 responden. Penelitian oleh Huwaida, dkk (2016) mengenai "Faktor-Faktor Risiko Yang Berhubungan Dengan Konsentrasi Timbal Dalam Darah Pada Pekerja di Perusahaan Rokok Wido di Kabupaten Kudus" menunjukkan bahwa ada hubungan antara kebiasaan merokok dengan konsentrasi timbal dalam darah responden. Hal ini menunjukkan bahwa pada pekerja dengan kebiasaan merokok memiliki resiko dua kali lebih besar untuk konsentrasi timbal dalam darah daripada yang tidak mempunyai kebiasaan merokok.

Berdasarkan penelitian yang telah dilakukan, operator Stasiun Pengisian Bahan Bakar (SPBU) merupakan kelompok pekerja yang memiliki resiko terpapar oleh bahan kimia yang berbahaya bagi kesehatan, terutama timbal dari bensin dan emisi gas kendaraan bermotor yang menunggu antrian pengisian bahan bakar atau kendaaran yang berangkat setelah selesai mengisi bahan bakar. Posisi SPBU yang biasanya didekat jalan raya dapat meningkatkan resiko terpaparnya operator dengan polutan timbal dari asap kendaraan bermotor yang melaju di jalan raya (Almunjiat et al, 20l6).

Operator SPBU adalah salah satu kelompok pekerja yang terpapar uap bahan bakar secara langsung, selain paparan langsung, kebiasaan merokok dapat meningkatkan resiko gangguan kesehatan. Penelitian ini dilakukan dengan tujuan untuk mengetahui kadar timbal yang terdapat di dalam darah operator SPBU wilayah Karanganyar.

\section{METODOLOGI}

\section{ALAT DAN BAHAN}

Spektrofotometer serapan atom (SSA), Labu ukur 100 $\mathrm{mL}$, Labu ukur $50 \mathrm{~mL}$, Botol ulir, Mikropipet, Blue type, Pipet ukur $10 \mathrm{ml}$, Push ball, COD Reactor, Tabung reaksi besar, Corong, Kertas Whatman no. 40, Cup sampel, Darah EDTA, Larutan $\mathrm{Pb}(\mathrm{NO} 3)_{2}$, Batu didih, larutan $\mathrm{HNO}_{3}$ pekat, Aquadest.

\section{METODE PELAKSANAAN}

Jenis penelitian yang digunakan adalah Deskriptif Analitik serta menggunakan desain penelititian Cross sectional. Pengambilan sampel dilakukan di SPBU Wilayah Karanganyar. Waktu penelitian Karya Tulis Ilmiah ini dilakukan pada bulan Mei-Agustus 2019. Teknik sampling yang digunakan dalam penelitian ini adalah Purposive Sampling yaitu Teknik pengambilan sampel berdasarkan kriteria yang telah ditentukan oleh 
peneliti. Penelitian menggunakan instrumentasi Spektrofotometer Serapan Atom (SSA) AA 7000.

\section{Prosedur Penelitian}

\section{Persiapan larutan sampel (Destruksi Basah)}

Siapkan alat dan bahan yang akan digunakan, lakukan pengambilan darah vena sebanyak $3 \mathrm{cc}$ dan ditambahkan dengan antikoagulan EDTA. Kemudian sampel dipipet sebanyak 0,5 $\mathrm{ml}$ dan masukkan kedalam labu ulir yang sudah diberi batu didih. Selanjutnya ditambahkan $\mathrm{HNO}_{3}$ pekat $0,5 \mathrm{ml}$, lalu destruksi dengan menggunakan COD reactor selama 60 menit dengan suhu $100^{\circ} \mathrm{C}$. Sampel didinginkan sampai suhu kamar kemudian ditambahkan aquadest sebanyak $9 \mathrm{ml}$, dan dihomogenkan. Tahap selanjutnya penyaringan dengan menggunakan kertas Whatman no. 40 kedalam tabung reaksi. Sampel siap dibaca dengan menggunakan alat Spektrofotometer Serapan Atom pada panjang gelombang $283,3 \mathrm{~nm}$.

\section{Pembuatan Larutan Standar}

Dibuat larutan standar timbal Ippm menggunakan labu ukur $100 \mathrm{~mL}$. Dengan memipet 0,05ml larutan $\mathrm{Pb}$ ready made 1000ppm. Kemudian dimasukkan dalam labu ukur $100 \mathrm{ml}$ dan ditambahkan aquadest sampai tanda batas, dikocok hingga homogen. Dibuat larutan standar 0,01 ppm, 0,02 ppm, 0,05 ppm, 0,08 ppm, 0,10 ppm, 0,120 ppm dengan memindahkan masing-masing $0,5 \mathrm{~mL}, \mathrm{I} \mathrm{mL}, 2,5 \mathrm{~mL}$, $4 \mathrm{~mL}, 5 \mathrm{~mL}, 6 \mathrm{ml}$ larutan standar I ppm ke dalam labu ukur $50 \mathrm{~mL}$, Masing-masing diencerkan dengan aquadest sampai tanda batas, kemudian dikocok hingga homogen, Dibaca dengan menggunakan alat Spektrofotometer Serapan Atom pada panjang gelombang 283,3 $\mathrm{nm}$.

\section{Pembuatan Kurva Kalibrasi}

Kurva kalibrasi dibuat dengan mengukur larutan standar pada SSA dengan panjang gelombang $283,3 \mathrm{~nm}$ dalam beberapa macam konsentrasi. Selanjutnya dibuat grafik antara konsentrasi dan absorbansi dengan menggunakan Microsoft excel ditentukan persamaan garis lurusnya yaitu regresi liner yaitu $y=a x+b$.

\section{Absorbansi Sampel}

Hasil pengukuran absorbansi sampel darah yang telah didestruksi diukur menggunakan Spektrofotometer Serapan Atom AA 7000. Persamaan garis regresi yaitu $y=0,00032993 x-$ 0,00016233 dan nilai $R^{2}=0,9906$. Kemudian dilakukan perhitungan kadar timbal dalam darah dengan menggunakan rumus $y=a x+b, x$ merupakan konsentrasi kadar timbal dan y merupakan absorbansi sampel.

\section{HASIL DAN PEMBAHASAN}

SPBU merupakan salah satu tempat terjadinya pencemaran udara yang diakibatkan oleh asap kendaraan bermotor dan uap dari bahan bakar motor. Paparan timbal berasal dari kendaraan bermotor yang sebagian besar menggunakan bensin yang mengandung Tetra Ethyl Lead (TEL). Pembakaran dari bensin yang mengandung Tetra Ethyl Lead (TEL)akan diubah menjadi bromida timah hitam lalu dilepaskan dalam bentuk uap yang mengandung logam berat timbal yang akan memperburuk kualitas udara dan timbal akan terakumulasi di dalam tubuh. Tempat pengambilan sampel dilakukan di SPBU wilayah Karanganyar. SPBU ini strategis pinggir jalan,ramai lalu lalang kendaraan bermotor, dan terdapat kemacetan di wilayah tersebut. Pemeriksaan kadar timbal dalam darah operator SPBU tersaji pada tabel I.

Tabel I. Hasil pemeriksaan kadar timbal dalam darah operator SPBU

\begin{tabular}{ccccc}
\hline $\begin{array}{c}\text { Kode } \\
\text { Sampel }\end{array}$ & $\begin{array}{c}\text { Kebiasaan } \\
\text { merokok } \\
\text { (batang/hari) }\end{array}$ & $\begin{array}{c}\text { Kadar } \\
\text { Timbal } \\
(\boldsymbol{\mu g} / \mathbf{d L})\end{array}$ & $\begin{array}{c}\text { Amban } \\
\mathbf{g} \text { batas } \\
\mathbf{C D C}\end{array}$ & Hasil \\
$(\boldsymbol{\mu g} / \mathbf{d L})$ & \\
\hline AI & 20 & $\mathrm{I}, 7854$ & $<10$ & Normal \\
A2 & 6 & 1,2049 & $<10$ & Normal \\
A3 & 10 & 1,6656 & $<10$ & Normal \\
A4 & 7 & 1,2825 & $<10$ & Normal \\
A5 & 8 & 1,4950 & $<10$ & Normal \\
\hline
\end{tabular}


Operator SPBU dapat memiliki resiko untuk terpapar langsung oleh timbal yang berasal dari uap kendaraan bermotor. Mayoritas operator SPBU adalah laki-laki dan beberapa memiliki kebiasaan merokok. Penelitian ini fokus kepada 5 responden yang memiliki kebiasaan merokok. Operator SPBU yang memiliki kebiasaan merokok diperkirakan memiliki dua kali lebih besar beresiko terpapar timbal daripada operator SPBU yang tidak memiliki kebiasaan merokok (Huwaida, 2016). Paparan resiko tinggi dari pekerjaan tersebut berhubungan langsung dengan bahan bakar kendaraan bermotor yang mengandung timbal, disamping itu juga dari komposisi rokok dengan kandungan timbal.

Sampel responden yang di dapatkan dilakukan pemeriksaan kadar timbal dalam darah menggunakan Spektrofotometer Serapan Atom AA 7000. Preparasi sampel dilakukan terlebih dahulu untuk dapat mengetahui kadar timbal dalam darah. Preparasi sampel dilakukan dengan metode destruksi. Penelitian kali ini menggunaan metode destruksi basah. Destruksi basah adalah pemanasan sampel dengan adanya larutan pengoksidasi yang kuat yang apabila dilakukan pemanasan suhu tinggi $\left(100^{\circ} \mathrm{C}\right)$ dan waktu yang lama maka sampel akan teroksidasi sempurna meninggalkan berbagai elemen-elemen pada larutan asam dalam bentuk senyawa anorganik yang sesuai untuk dianalisis. Variasi jam kerja pada responden operator yang diambil sampel darahnya dimulai dari shif pagi yaitu pukul 07.0014.00 WIB; shif siang yaitu pukul 14.00-2I.00 WIB; shif malam yaitu pukul 21.00-07.00 WIB. Penelitian dilakukan pada menjelang sore hari antara perpindahan shif pagi ke siang hari. Tingkat kepadatan lalu lintas kendaraan bermotor pada jam tersebut menyebabkan polusi udara.

Proses destruksi dilakukan tergantung pada sifat zat organik dalam sampel, sifat zat anorganik dalam bahan, logam berat yang akan dianalisa serta sensitivitas yang digunakan (Hidayati, 20I3). Penambahan $\mathrm{HNO}_{3}$ berfungsi untuk memutuskan ikatan senyawa kompleks organologam karena mempunyai sifat oksidator yang kuat. $\mathrm{HNO}_{3}$ memiliki titik didih $121^{\circ} \mathrm{C}$ sehingga penggunaan suhu $100^{\circ} \mathrm{C}$ untuk mencegah larutan $\mathrm{HNO}_{3}$ tidak cepat habis sebelum proses destruksi selesai. Dilakukan pemanasan suhu tinggi untuk mempercepat pemutusan ikatan organologam menjadi anorganik (Wulandari, 2013).

Pemeriksaan kadar timbal dengan Spektrofotometer Serapan Atom dibaca pada panjang gelombang 283,3 nm. Hasil dari pemeriksaan kadar timbal dalam darah para operator menunjukkan hasil dalam ambang batas normal menurut CDC (Center for Disease Control) tahun $20 \mathrm{I}$ I, yaitu < $10 \mu \mathrm{g} / \mathrm{dl}$. Kebiasaan merokok merupakan salah satu faktor yang dapat meningkatkan kadar timbal dalam darah. Semakin banyak konsumsi rokok setiap harinya maka akan semakin meningkatkan kadar timbal di dalam darah. Komposisi rokok salah satunya mengandung timbal. Satu batang rokok dapat menghasilkan 0,5 $\mu \mathrm{g}$ timbal, sehingga dalam satu bungkus rokok ( \pm isi 20 batang) yang dihisap dalam satu hari dapat menghasilkan $10 \mu \mathrm{g}$ timbal. Sementara ambang batas bahaya timbal yang masuk dalam tubuh $20 \mu \mathrm{g}$ per hari. Sedangkan pada perokok berat biasanya bisa menghabiskan rata-rata 2 bungkus rokok perhari dan semakin banyak zat berbahaya yang masuk dalam tubuh (Herawati, 2010).

Hasil penelitian ini menunjukkan kebiasaan merokok tidak dapat menentukan seberapa besar kandungan timbal dalam darah. Operator SPBU dengan kebiasaan merokok (batang/hari) yang lebih sedikit memiliki kandungan timbal yang lebih tinggi dibandingkan operator yang memiliki kebiasaan merokok lebih banyak setiap harinya. Hal ini dapat disebabkan oleh faktor faktor lain yang mungkin dapat mempengaruhinya.

Berdasarkan tabel I diperoleh hasil dari pemeriksaan kadar timbal dalam darah yaitu pada sampel dengan kode Al dengan kebiasaan merokok 20batang/hari

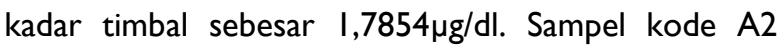
kebiasaan merokok 6batang/hari kadar timbal sebesar I,2049 $\mu \mathrm{g} / \mathrm{dl}$. Sampel kode A3 kebiasaan merokok I Obatang/hari kadar timbal sebesar I,6656 g/dl. Sampel 
kode A4 kebiasaan merokok 7batang/hari kadar timbal sebesar I,2825 $\mu \mathrm{g} / \mathrm{dl}$. Sampel kode A5 kebiasaan merokok 8batang/hari kadar timbal sebesar I,4950 $\mu \mathrm{g} / \mathrm{dl}$.

Sampel dengan kode AI, memiliki kadar timbal paling tinggi diantara semuanya karena memiliki kebiasaan merokok paling tinggi juga yaitu sebanyak 20 batang/harinya. Hal ini menjadi faktor yang meningkatkan kadar timbal dalam sampel tersebut. Semakin tinggi frekuensi merokok setiap harinya maka akan semakin tinggi kadar timbal dalam darah. Disamping itu diikuti dengan faktor faktor lainya yang mungkin juga dapat mempengaruhi hasil pemeriksaan seperti masa kerja, umur, jenis kelamin, status gizi, penggunaan Alat Pelindung Diri, dll (Huwaida, 2016). Kemudian sampel dengan kode A2,A4 dan A5 memiliki kesamaan kebiasaan merokok yaitu 6-8batang/hari. Sampel AI dan A3 memiliki hasil kadar timbale yang lebih tinggi, disebabkan karena faktor lain salah satunya yaitu masa kerja operator yaitu 9 tahun dibanding sampel AI II tahun dan A3 yaitu 7 tahun. Sampel A2 memiliki kadar timbal yang lebih rendah daripada sampel lainnya, hal ini dapat dikarenakan faktor-faktor lain yang mempengaruhi hasil timbal. Sampel A2 menunjukkan hasil yang lebih rendah dapat disebabkan karena pola hidup yang sehat dari responden, asupan gizi yang cukup. Serta pada sampel AI menunjukkan hasil yang lebih tinggi dapat disebabkan oleh pola hidup yang tidak sehat, asupan gizi yang kurang, serta faktor dari imunologi yang cenderung turun sehingga dapat dengan mudah terkena paparan timbal.

\section{KESIMPULAN}

Berdasarkan penelitian yang telah dilakukan dapat disimpulkan bahwa seluruh sampel operator SPBU wilayah Karanganyar yang mempunyai kebiasaan merokok memiliki kadar timbal dalam darah dalam batasan normal, dibawah ambang batas normal) yang di tetapkan oleh CDC (20II), yaitu < $10 \mu \mathrm{g} / \mathrm{dl}$.

\section{UCAPAN TERIMA KASIH}

Ucapan terima kasih kepada STIKES Nasional yang telah memberikan fasilitas dan pendanaan kepada peneliti untuk dapat melaksanakan kegiatan penelitian ini. Semoga hasil dari penelitian ini dapat bermanfaat bagi semua pihak dan masyarakat luas pada umumnya.

\section{REFERENSI}

I. Hasbiah, A, Mulyatna, L, Musaddad, F. (20I6). Studi Identifikasi Pencemaran Udara oleh Timbal (Pb) pada Area Parkir. Bandung: Universitas Pasundan.

2. Gusnita, D. (20/2). Pencemaran Logam Berat Timbal $(\mathrm{Pb})$ di Udara dan Upaya Penghapusan Bensin Bertimbal. Lapan: Berita Dirgantara (13).

3. Suhardjo, D. (2007). Analisis Kebutuhan Ruang Terbuka Hijau Dalam Mengendalikan Tingkat Pencemaran Gas Buang Kendaraan Bermotor. Yogyakarta : Universitas Islam Indonesia

4. Naria, E. (2005). Mewaspadai Dampak Bahan Pencemar Timbal $(\mathrm{Pb})$ di Lingkungan Terhadap Kesehatan. Universitas Sumatera Utara: Bagian Kesehatan Lingkungan Fakultas Kesehatan Masyarakat. Jurnal Komunikasi Penelitian Vol.I7.

5. Ayu, F, Afridah,W, Nourma, M. (2016). Hubungan Karakteristik Pekerjaan Dengan Kadar Timbal Dalam Darah (Pb) Pada Operator Spbu di Kecamatan Talamanrea Kota Makassar Tahun 2016. Surabaya: Universitas Nahdlatul Ulama Surabaya.

6. Laila, N., \& Iting, S. (20|3). Kadar Timbal Darah Dan Keluhan Kesehatan Pada Operator Wanita SPBU. Jakarta: UIN Syarif Hidayatullah Jakarta.

7. Huwaida, A., Rahardjo, M., Setiani, O. (20/6). Faktor - Faktor Yang Berhubungan Dengan Konsentrasi Timbal (Pb) Dalam Darah Pada Pekerja Di Perusahaan Rokok Wido Di Kabupaten Kudus. Semarang: Universitas Diponegoro.

8. Almunjiat, E, Sabilu, Y, Ainurafiq. (2016).Analisis Risiko Kesehatan Akibat Pajanan Timbal (Pb) Melalui Jalur Inhalasi Pada Operator di Stasiun Pengisian Bahan Bakar Umum (SPBU) di Kota Kendari Tahun 2016 (Studi di SPBU Tipulu, Wuawua, Anduonohu dan SPBU Lepo-lepo). Kendari: Fakultas Kesehatan Masyarakat Universitas Halu Oleo. 
9. Hidayati, E N. (20|3). Perbandingan Metode Destruksi Pada Analisis Pb Rambut Dengan AAS. Skripsi. Universitas Negeri Semarang.

10. Wulandari, E A, Sukesi. (2013). Preparasi Penentuan Kadar Logam $\mathrm{Pb}, \mathrm{Cd}$ dan $\mathrm{Cu}$ dalam Nugget Ayam Rumput Laut Merah (Eucheuma cottonii). Surabaya : Institut Teknologi Sepuluh Nopember. Jurnal Sains dan Seni.

II. Herawati, M H. (20I0). Bahan Yang Mengandung Zat Adiktif Pada Produk Rokok Dan Dampaknya Terhadap Kesehatan. Puslitbang Biomedis dan Farmasi Badan Litbangkes Kemenkes RI. 